\begin{tabular}{|l|l|l||}
\hline \multicolumn{2}{|c|}{ PublisherInfo } \\
\hline \hline PublisherName & $:$ & BioMed Central \\
\hline \hline PublisherLocation & $:$ & London \\
\hline \hline PublisherImprintName & $:$ & BioMed Central \\
\hline \hline
\end{tabular}

\title{
Diphtheria exposed during comeback
}

\begin{tabular}{|l|l|l||}
\hline \multicolumn{2}{|c|}{ ArticleInfo } \\
\hline \hline ArticleID & $:$ & 4875 \\
\hline \hline ArticleDOI & $:$ & $10.1186 /$ gb-spotlight-20031107-01 \\
\hline \hline ArticleCitationID & $:$ & spotlight-20031107-01 \\
\hline \hline ArticleSequenceNumber & $:$ & 227 \\
\hline \hline ArticleCategory & $:$ & Research news \\
\hline ArticleFirstPage & $:$ & 1 \\
\hline \hline ArticleLastPage & $:$ & 2 \\
\hline \hline & & RegistrationDate : 2003-11-7 \\
\hline ArticleHistory & $:$ & OnlineDate \\
\hline \hline ArticleCopyright & $:$ & BioMed Central Ltd2003 \\
\hline \hline ArticleGrants & $:$ & \\
\hline \hline ArticleContext & $:$ & 130594411 \\
\hline \hline
\end{tabular}




\section{Cathy Holding}

Email: cholding@hgmp.mrc.ac.uk

An effective vaccination program has meant that diphtheria is rarely encountered in the United Kingdom and other developed countries, but continuing outbreaks in the developing world are an important public health concern. In the November 15 Nucleic Acids Research, Ana Maria CerdeñoTárraga and colleagues at the Sanger Institute report the application of genomic analysis technologies to the causative agent, Corynebacterium diphtheriae. They reveal recent horizontal acquisition of genes involved in survival, attachment, and virulence, enabling characterization of pathogenesis proteins that could be used for diagnostic and antibacterial therapies or as potential vaccine candidates (Nucleic Acids Research 2003, 31:6516-6523).

Cerdeño-Tárraga et al. sequenced the whole genome of $C$. diphtheriae biotype gravis NCTC13129 after shotgun cloning into pUC18 libraries and identified coding regions and proteins that were curated manually. A single circular chromosome of nearly $2.5 \mathrm{Mb}$ with no plasmids was identified, including 13 regions of unusually high GC content indicative of recent gene acquisition containing genes contributing to the pathogenicity of the organism - termed "pathogenicity islands." These encode the majority of factors such as fimbriae (pili-like surface structures involved in initial bacterial infection not previously described in C. diphtheriae) and fimbriae-related genes, as well as iron uptake systems - specialized survival mechanisms for pathogenic bacteria. The location and GC content of the tox gene, at the righthand end of an integrated corynephage, also suggested recent acquisition by horizontal gene transfer. Core regions containing cell wall components contributing to pathogenicity were identified, including an arabinogalactan polymer involved in adhesion.

"This project was initiated to generate the genomic sequence and analysis of a pathogenic Corynebacterium in order to help develop and make the most of these new genetic systems so as to gain a better understanding of the biology and virulence of this microorganism. The recent diphtheria epidemics have emphasized that continuous expansion in the depth of knowledge of basic biological and genetic mechanisms, which could affect the organism's adaptability and pathogenicity, will remain as one of our most powerful tools in the fight against diphtheria," the authors conclude.

\section{References}

1. Streptococcus and Diphtheria Reference Unit, Central Public Health Laboratory, [http://cphl.phls.org.uk/divisions/rsil/strepto_dip_ref.htm]

2. Nucleic Acids Research, [http://nar.oupjournals.org/]

3. The Wellcome Trust Sanger Institute, [http://www.sanger.ac.uk/]

This PDF file was created after publication. 